Case Series

\title{
Treatment of advanced rectal cancers: Cylindrical abdominoperineal excision of rectum
}

\author{
${ }^{1}$ Nirmal Lamichhane, ${ }^{2}$ Kenneth G walker \\ ${ }^{1}$ Dept of Surgical Oncology, BP Koirala Memorial Cancer Hospital, Bharatpur, Nepal. \\ ${ }^{2}$ Dept of Colorectal Surgery, Raigmore Hospital, Inverness, UK
}

Correspondence: Nirmal Lamichhane, Dept of Surgical Oncology, BP Koirala Memorial Cancer Hospital, Bharatpur, Nepal

E-mail: Nlamichhane@hotmail.com

\begin{abstract}
Introduction: Treatment for patients with locally advanced low lying rectal cancer differs significantly from patients with rectal cancer restricted to the mesorectum. They require multimodality treatment, including preoperative chemo-radiation and extended surgical resection. Cylindrical abdominoperineal excision of rectum (C-APER) along with possible composite pelvic organ resection is a surgical method to remove an adequate circumferential margin.

Method: Patients with the diagnosis of advanced rectal cancers over a period of 9 months are included in this study. Therapeutic approach of C-APER is taken for these patiens with focus on multimodality treatment protocols to downstage the tumours and extended resections to enable complete removal of all tumour tissue with clear surgical margins. Consecutive review of cases of advanced rectal cancer to their immediate surgical outcome were done.

Results: Five patients with compromised CRM in MRI of rectum, 4 were treated with Neoadjuvant FOLFOX 6 regimen chemotherapy 3 cycles and Short course Radiotherapy. All underwent surgery 6-8 weeks after treatment. The pelvic floor was repaired with biological mesh in 1 and synthetic mesh in 4. The pathological stage of disease remained T3 and above despite neoadjuvant treatment in majority of patients but non of them had positive CRM. The wound complication rates were high in the perineum with serous discharge in almost every patient and one patient needing long term vacuum assisted dressing in the community.

Conclusion: The surgery is technically feasible with acceptable morbidity in short term with possible long term outcome of reduced loco-regional failure.

Keywords: rectal cancer, cylindrical abdominoperineal excision of rectum, composite organ resection, radiotherapy.
\end{abstract}

\section{Introduction}

The majority of patients with primary rectal cancer present with a tumour located within the mesorectal fascia, which is generally treated with total mesorectal excision (TME). ${ }^{1}$ In $10 \%$ of all rectal cancer patients the tumour extends close to, into or beyond mesorectum and enveloping fascia propria ie T3/4. ${ }^{2}$ These numbers could be higher in Nepal. Some of these tumours invade the adjacent structures and therefore have a higher risk of developing local recurrence. ${ }^{3}$ Patients with these primary locally advanced rectal cancers are historically difficult to treat with surgery alone. Outcome has significantly improved using multimodality treatment. ${ }^{4}$
For low lying rectal lesions, the involvement of circumferential margin (CRM) is very common with conventional abdominoperineal excision (APE). ${ }^{5}$ This is mainly due to removal of inadequate tissue at the level of the tumour. Bearing in mind the tapering of the mesorectum toward the levators, it is important for surgeons to understand it is likely that there is less tissue for the carcinoma to traverse before involving the surgical plane of resection in the low mesorectum and anal canal. ${ }^{6}$ This usually gives rise to close CRM in APER specimens. We know that positive CRM is directly related to increased local recurrence and subsequent decrease in survival. ${ }^{7}$ This gives a clue that more aggressive/wider surgical resection is required for low lying rectal tumours to reduce the local recurrence. 
There is evidence to suggest that the traditional APER may have changed over the last half century. The original description by Miles describes the abdominal dissection being performed down to the levator ani muscles, which were not incised at this point. The perineal dissection was then started, and he described a wide excision with removal of the coccyx and the removal of the levator ani by dividing them as far outwards as their origin from the 'white line' so as to include the lateral zone of spread. His description in 1910 confirms his perineal approach to the levators and he stated "these muscles are divided as far outwards as their origin from the pelvic wall." ${ }^{8}$ The perineal approach and the wider excision of the levators are different from the current technique of following the mesorectal fascia down to the levators. With more wide spread use of TME, surgeons have tended to taper the specimen even for APER. The original approach of Miles would result in more tissue being excised in the low rectum and might lead to a lower rate of CRM involvement.

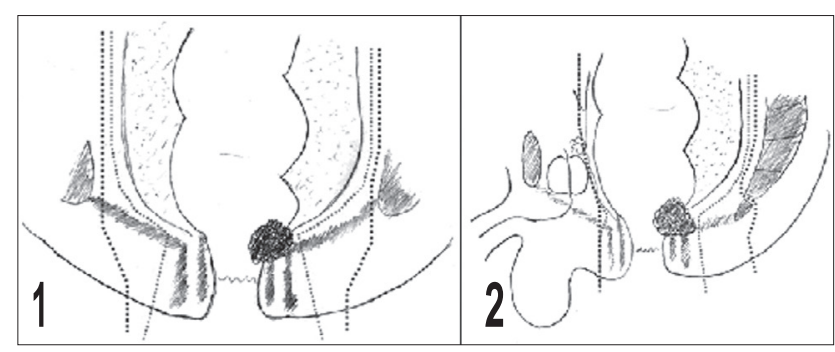

Figure 1 Diagram representation of "standard" (red lines) and cylindrical APER (blue lines), coronal plane.

Figure 2. Diagram of "standard" (red lines) and cylindrical APER (blue lines), sagittal plane.

Recently, Dr. T. Holm of the Karolinska Institute in Stockholm has been promoting the excision of the anus and levator muscles from below with the patient lying prone. This mainly perineal approach results in a completely different resection specimen with more tissue removed and a surgical resection margin much farther away from the muscularis propria and the sphincters. The levator muscles are included in the specimen with their natural relationships intact. Removal of the coccyx improves the access to the levator plane and facilitates the wider operation and is routinely performed by Dr. Holm in Stockholm (fig 1 and 2). ${ }^{9}$

It is not an absolute prerequisite to remove the coccyx in this type of operation and can be omitted, but the surgical difficulty may be increased. A randomized trial of removal versus retention has not been performed. The resulting pelvic floor deficit is covered by surgical flaps or artificial mesh repair. This operation should be considered in all low rectal pT3 tumours. The greater access of the perineal approach should reduce the frequency of perforation of the specimen and, in our experience, the common problem of the surgical margin entering the muscle wall low in the rectum.

This wider surgical resection sometimes involves not only the removal of the total mesorectum, but en bloc resection of involved structures around it. This exenterative operation sometimes needs the removal of urinary bladder, prostate, vagina, uterus and adenexa.

\section{Methods}

Therapeutic approach of C-APER is taken for 5 advanced rectal cancers in 9 months period. This is discussed with a focus on multimodality treatment protocols to downstage the tumours and extended resections to enable complete removal of all tumour tissue with clear surgical margins.

\section{Surgical technique}

The patient under general anesthetic is put in Lloyd-Davies position with routine preparation of the abdominal part. Standard mobilization of left colon, sigmoid colon and rectum is done up to the level of about $\mathrm{S} 4 / 5$ of the vertebrae before the specimen starts to taper down. This part can be performed laparoscopically or in an open fashion. The sigmoid end stoma is matured at the left side of the abdomen at a previously marked area. The abdomen is closed and dressed. The patient is then changed to prone and jack knife position, legs slightly spread apart. A keyhole like incision is made extending form coccyx to around the anus (Figure 3).
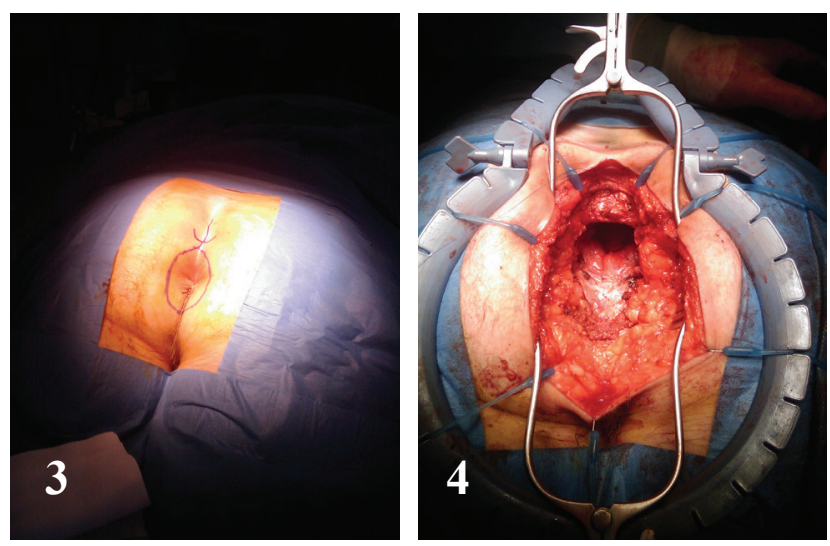

Figure 3. Pre-surgical marking at perineum

Figure 4. Perineal surgery in progress, loan star retractor in situ. 

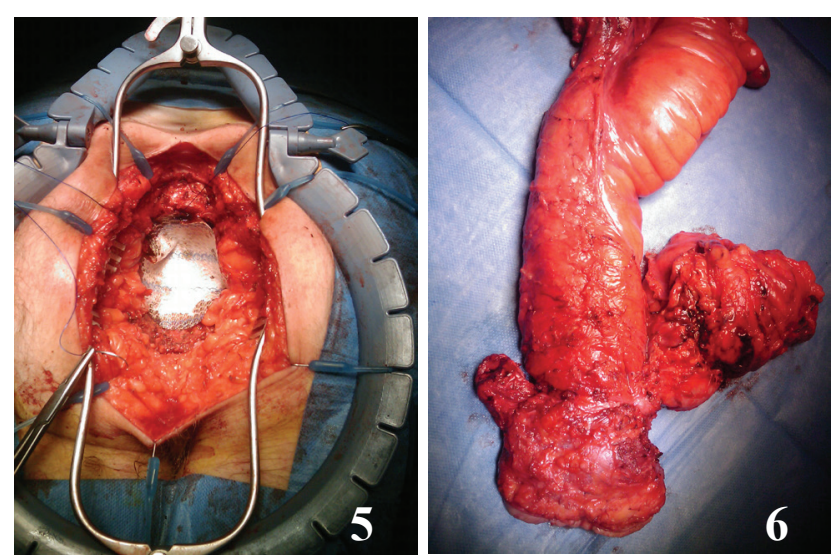

Figure 5. Perineal defect being closed with a mesh

Figure 6. Specimen in situ contains coccyx posteriorly, urinary bladder and prostate in front.

Levator muscles covering the specimen.

The incision is deepened around the anus in the extrasphincteric fat plane to reach levator muscles (Figure 4). The muscles are divided wide laterally under vision and will remain attached to the rectum leaving a large pelvic floor defect. In the same plane, the coccyx is divided and kept with the specimen. The perineal plane is continued upwards to meet with the pelvic plane and the specimen is dissected out from the prostatic capsule or vaginal wall.
Sometimes this anterior dissection is made easy by partly delivering the specimen. Then the specimen is delivered from the perineum. The wound lavage performed and hemostasis secured. The defect of levator muscle is closed with a biological or synthetic mesh (Figure 5). The representative delivered specimen is shown in Figure 6. Suction drains are placed above and below the mesh. The fat layer and skin are closed in layers.

\section{Results}

The author was involved in 5 patients who were treated with this new type of surgery in a one year fellowship post. Majority of patients were in 7 th decade of life and mainly presented with $\mathrm{P} / \mathrm{R}$ bleeding ( Table 1 ). In all the patients MRI of rectum revealed the Compromised status of CRM before commencing treatment. Neoadjuvant FOLFOX 6 regimen chemotherapy for 3 cycles and Short course Radiotherapy was given in 4 patients (Table 2) . Patients had waited for 6-8 weeks before surgery. C-APER as described above was performed. One patient among these underwent pelvic exenteration for gross prostatic involvement. The pelvic floor was repaired with biological mesh in 1 and synthetic mesh in 4 patients (Table 2). The pathological stage of disease remained T3 and above despite neoadjuvant treatment in majority of patients but but non of them had positive CRM ( Table 3). The wound complication rates were high in the perineum with serous discharge in almost every patient and one patient needing long term vacuum assisted dressing in the community.

Table 1: Pre-treatment data of the patients of APER.

\begin{tabular}{|c|c|c|c|c|c|}
\hline Case & 1 & 2 & 3 & 4 & 5 \\
\hline Age (Yr) & 75 & 64 & 72 & 69 & 66 \\
\hline Sex & Female & Male & Female & Male & Male \\
\hline Duration & $2 / 12$ & $1.5 / 12$ & $3 / 12$ & $4 / 12$ & $6 / 12$ \\
\hline Presentation & Change in bowel habit & $\mathrm{p} / \mathrm{r}$ bleed & $\mathrm{p} / \mathrm{r}$ bleed & Mucoid stool & $\mathrm{p} / \mathrm{r}$ bleed \\
\hline $\mathrm{P} / \mathrm{R}$ exam & $\begin{array}{l}\text { Tethered lesion at } \\
6 \mathrm{~cm} \text { from the anal } \\
\text { verge. }\end{array}$ & $\begin{array}{l}\text { Ulcerative } \\
\text { lesions at } 4.5 \mathrm{~cm} \\
\text { form the anal } \\
\text { verge. }\end{array}$ & $\begin{array}{l}\text { Bulky lesion at } \\
\text { lower rectum }\end{array}$ & $\begin{array}{l}\text { Fixed tumor at } \\
\text { anterior wall of } \\
\text { rectum }\end{array}$ & $\begin{array}{l}\text { Tethering } \\
\text { tumor at lower } \\
\text { rectum }\end{array}$ \\
\hline
\end{tabular}




$\begin{array}{llllll}\begin{array}{l}\text { Pre op } \\ \text { Biopsy }\end{array} & \begin{array}{l}\text { Adenoca in villous } \\ \text { adenoma }\end{array} & \text { Adenoca } & \begin{array}{l}\text { Poorly diff } \\ \text { mucinous } \\ \text { adenoca }\end{array} & \text { Adenoca } & \text { Adenoca } \\ \text { MRI } & \text { CRM compromised } & \begin{array}{l}\text { Pelvic nodes } \\ \text { present near the } \\ \text { levator muscles }\end{array} & \begin{array}{l}\text { Levator Muscle } \\ \text { invasion }\end{array} & \begin{array}{l}\text { Prostatic } \\ \text { capsule } \\ \text { invasion }\end{array} & \begin{array}{l}\text { Mesorectal } \\ \text { nodes } \\ \text { compromizing } \\ \text { the CRM. }\end{array} \\ \text { CT } & \begin{array}{l}\text { Solitary Liver } \\ \text { metastasis }\end{array} & \text { No distant mets } & \text { No distant mets } & \text { No distant mets } & \begin{array}{l}\text { No distant } \\ \text { mets }\end{array} \\ \text { Hb\% } & 120 & 130 & 91 & 140 & 136 \\ \text { Albumin } & 30 & 36 & 40 & 36 & 40 \\ \text { Colonoscopy } & \text { Full } & \text { Full } & \text { Full } & \text { Full } & \text { Full }\end{array}$

Abbreviations: P/R: per rectal, MRI: magnetic resonance imaging, CT: computed tomography, CRM: circumferential margin, $\mathrm{Hb}$ : hemoglobin.

Table 2: Treatment received

$\begin{array}{llllll}\text { Case } & \mathbf{1} & \mathbf{2} & \mathbf{3} & \mathbf{4} & \mathbf{5} \\ \begin{array}{l}\text { Neoadjuvant } \\ \text { chemo+RT }\end{array} & 5 / 52 & 5 / 52 & \text { non } & 5 / 52 & 5 / 52 \\ \begin{array}{l}\text { Surgery } \\ \text { Lap abdominal } \\ \text { and Open } \\ \text { perineal } \\ \text { surgery. }\end{array} & \begin{array}{l}\text { Open abdominal } \\ \text { and perineal } \\ \text { surgery }\end{array} & \begin{array}{l}\text { Open } \\ \text { abdominal and } \\ \text { perineal surgery }\end{array} & \begin{array}{l}\text { Open abdominal } \\ \text { surgery doing colon } \\ \text { and bladder and } \\ \text { prostate. Prone } \\ \text { perineal surgery }\end{array} & \begin{array}{l}\text { Lap abdominal } \\ \text { surgery } \\ \text { surgerineal }\end{array} \\ \begin{array}{l}\text { Mesh used in } \\ \text { pelvic repair }\end{array} & \text { Permacol } & \text { Proceed } & \text { Permacol } & \text { Proceed } & \text { Proceed }\end{array}$

Permacol: Biological Bovine collagen Mesh, Proceed: Polypropylene synthetic mesh

Table 3: Pathology

\begin{tabular}{|c|c|c|c|c|c|}
\hline Case & 1 & 2 & 3 & 4 & 5 \\
\hline Histology & $\begin{array}{l}\text { Adenocarcinoma in } \\
\text { villous adenoma. }\end{array}$ & Adeno ca & $\begin{array}{l}\text { Poorly diff } \\
\text { mucinous } \\
\text { adenoca }\end{array}$ & $\begin{array}{l}\text { Poorly diff } \\
\text { adenoca }\end{array}$ & Adeno ca \\
\hline Grade & G2 & $\mathrm{G} 2$ & G3 & G3 & $\mathrm{G} 2$ \\
\hline $\begin{array}{l}\text { Lymphovascular } \\
\text { invasion }\end{array}$ & - & - & + & + & - \\
\hline Nodal involvement & $3 / 14$ & $0 / 8$ & $0 / 13$ & $0 / 11$ & $0 / 9$ \\
\hline TNM & yPT3,yPN2, yM1 & $\begin{array}{l}\text { yPT3,yPN0, } \\
\text { M0 }\end{array}$ & T1,N0, M0 & $\begin{array}{l}\text { yPT4,yPN0, } \\
\text { M0 }\end{array}$ & $\begin{array}{l}\text { yPT3, yPN0, } \\
\text { M0 }\end{array}$ \\
\hline $\begin{array}{l}\text { CRM from the } \\
\text { disease }\end{array}$ & Not involved & $11 \mathrm{~mm}$ & Not involved & Not involved & $4.5 \mathrm{~mm}$ \\
\hline
\end{tabular}

Abbreviations: TNM: tumor, nodes, metastasis; 


\section{Discussion}

For low lying advanced rectal tumours, the main strategy to attain local control and prolong survival is by multimodality treatment. Before commencing treatment, accurate imaging of the disease for staging is very important. MRI (CT scans) is the method of choice for the local staging of T3/4 tumours. ${ }^{10}$ Endorectal ultrasound is good for T1/2 tumours. CT scan of chest and abdomen will assess for distant metastasis.

Long course chemoradiotherapy of 5 weeks and waiting time of 6-8 weeks is optimal for ideal tumour shrinkage. ${ }^{11}$ In our series, cylindrical abdomino-perineal resection in prone position (C-APER) is chosen as the main surgical technique as described by Dr Holm in Sweden. The main difference from the conventional surgery is the anus and levator muscles are excised from below with the patient lying in prone position. This mainly perineal approach results in a completely different resection specimen with more tissue removed and a surgical resection margin much farther away from the muscularis propria and the sphincters (Figure 1 and 2). The levator muscles are included in the specimen with their natural relationships intact. Removal of coccyx improves the access to the levator plane and facilitates the wider operation. ${ }^{12}$ The perineal defect was closed with a mesh (biological or synthetic) and closed over a drain. Other theoretical benefits are low rate of positive CRM, less intraoperative bowel perforations which translates into low local recurrence rate. Obviously the length operative time and of hospital stay and perineal wound-related complications are high. ${ }^{18}$

West NP et al., form European Extralevator Abdominoperineal Excision Study group described the wider extra levator resection of the rectal stump and showed the CRM is less involved but the perineal wound complication rate is high. ${ }^{13}$ The same group in Journal of Clinical Oncology reported the cylindrical technique removed more tissue in the distal rectum and in all slices that contained tumour compared with the standard operation (both $\mathrm{p}<0.0001$ ). Greater distance was observed from the muscularis propria or internal sphincter to the anterior, posterior, and lateral resection margins (all $\mathrm{p}<0.0001$ ). This was associated with lower circumferential resection margin $(\mathrm{CRM})$ involvement $(14.8 \% \mathrm{v} 40.6 \%$; $=0.013)$ and intra-operative perforations $(3.7 \% \mathrm{v} 22.8 \%$; $=0.0255)$. An increase in the amount of tissue removed in the distal rectum $(\mathrm{p}<0.0001)$ was demonstrated by a single surgeon who changed from the standard to the cylindrical technique during the study period; the change was associated with a reduction in CRM positivity (from $36.2 \%$ to $12.5 \%$ ) and in perforations (from $12.8 \%$ to $0.0 \%$ ). They concluded this technique has the potential to improve patient outcomes substantially if appropriate surgical education programs are developed. ${ }^{14}$ Dalton et al., also concluded the prone position elAPE has a low circumferential resection margin involved rate and, through improved vision, reduces the risk of inadvertent tumour or specimen perforation. ${ }^{17}$

Youssef $\mathrm{H}$ et al., form Birmingham tried to analyze the root cause of the positive CRM in APR which was $26 \%$ in their study of 156 patients. Though there was obvious underestimation of CRM by MRI in 4 patients, the rest of the patient have no obvious cause for the involvement of CRM. ${ }^{15}$

In the cases where we did C-APER, none of the CRM was involved. This may be the contribution of pre-operative RT as well as the surgical method chosen in which more tissue is excised in prone position. C-APER would be the optimal technique for local disease clearance. Long term follow up studies will be necessary to show the local control rate and overall survival for this method.

Traditionally we have had a lower threshold for giving neo-adjuvant long-course chemoradiotherapy to low rectal cancers, than to mid or upper rectal cancers. T2, 3 or 4 cancers in the low rectum may be given such multimodality treatment, whereas in the mid rectum it is currently reserved for advanced T3 or T4 tumours (ie "margin-threatening"). The reason for this was the higher incidence of positive CRM and local recurrence after APER than after TME. However we may now reconsider this policy since adopting Cylindrical APER, if on longer follow-up it appears to abolish this difference.

Regarding complications, there are increased perineal wound complications in this group of patients which will be a trade off for the better local control and possible increased survival. Other authors used gluteal flap rotation and some other techniques of plastic surgical procedures to reduce the perineal wound complications. ${ }^{16}$

\section{Conclusion}

C-APER is promising in terms of getting clear CRM. The operation is technically feasible with some modifications in centers that are routinely performing APER operations. This may reduce the local recurrence and this in long term will translate into improved survival.

\section{References}

1. Beart R W. Multidisciplinary Management of Patients with Advanced Rectal Cancer. Clin CancerRes. 2007; 13(22): 6890-93. 
2. de Wilt JHW, Vermaas M, Ferenschild FTJ, Verhoef C. Management of Locally Advanced Primary and Recurrent Rectal Cancer. Clinics in colon and rectal surgery. 2007; 20(3): 255-263.

3. Holm T, Cedermark B, Rutqvist LE. Local recurrence of rectal adenocarcinoma after 'curative' surgery with and without preoperative radiotherapy. Br J Surg. $1994 ; 81: 452-455$.

4. Balch GC, DeMeo A, Guillem JG. Modern management of rectal cancer: A 2006 update. World J Gastroenterol. 2006; 12(20): 3186-3195.

5. Dulk M D, Marijnen CAM, Putter H, et al. Risk Factors for Adverse outcome in patients with rectal cancer treated with an abdominoperineal resection in the total mesorectal excision trial. Ann Surg. 2007; 246: 83-90.

6. Birbeck KF, Macklin CP, Tiffin NJ, et al. Rates of circumferential resection margin involvement vary between surgeons and predict outcomes in rectal cancer surgery. Annals of surgery. 2008; 235(4): 449457.

7. Quirkea P, Steelec R, Monson J. Effect of the plane of surgery achieved on local recurrence in patients with operable rectal cancer: a prospective study using data from the MRC CR07 and NCIC-CTG CO16 randomized clinical trial. Lancet. 2009; 373(9666): 821-828.

8. Keighley R B M, Williams NS ed. Surgery of anus rectum and colon. $2^{\text {nd }}$ edition. London. WB sounders. 1997. page 1119 .

9. Sjövall A, Granath F, Cedermark B, Glimelius B, Holm T. Loco-regional Recurrence from Colon Cancer: A Population-based Study. Annals of Surgical Oncology 2009; 14(2): 432-440.

10. Brown B G, Daniels IR, Norman AR, Mason B, Cunningham D. MRI directed multidisciplinary team preoperative treatment strategy: the way to eliminate positive circumferential margins? British Journal of Cancer. 2006; 94: $351-357$.
11. Guillem J G, Chessin D B, Cohen A M, et al. Longterm Oncologic Outcome Following Preoperative Combined Modality Therapy and Total Mesorectal Excision of Locally Advanced Rectal Cancer. Ann Surg. 2005; 241: 0829-838.

12. Marr R, Birbeck K, Garvican J, et al. The Modern Abdominoperineal Excision: The Next Challenge After Total Mesorectal Excision. Ann Surg. 2005; 242: 74-82.

13. West NP, Anderin C, Smith KJ, Holm T, Quirke $\mathrm{P}$. Multicentre experience with extralevator abdominoperineal excision for low rectal cancer. Br J Surg. 2010; 97(4): 588-99.

14. West NP, Finan PJ, Anderin C, Lindholm J, Holm T, Quirke P. Evidence of the oncologic superiority of cylindrical abdominoperineal excision for low rectal cancer. J Clin Oncol. 2008; 26(21):3517-22.

15. Youssef H, Collantes EC, Rashid SH, Wong LS, Baragwanath P. Rectal cancer: involved circumferential resection margin - a root cause analysis. Colorectal Dis. 2009; 11(5): 470-4.

16. Holms T, Ljung A, Haggmark T, et al. Extended abdominoperineal resection with gluteus maximus flap reconstruction of the pelvic floor for rectal cancer. Br J Surg 2007; 94: 232-238.

17. Dalton RS, Smart NJ, Edwards TJ, Chandler I, Daniels IR. Short-term outcomes of the prone perineal approach for extra-levator abdomino-perineal excision (elAPE). Surgeon. 2012; 10(6): 342-6.

18. Perdawood SK, Lund T. Extralevator versus standard abdominoperineal excision for rectal cancer. Tech Coloproctol. 2015; 19(3): 145-52. 